\title{
INTENDED USE OF PROCEEDS AND THE PERFORMANCE OF INITIAL PUBLIC OFFERINGS (IPO).
}

\author{
Siti Azrina Adanan*, A’ieshah Abdullah Sani, Khair Syakira Bustamam , Amilia Saidin \\ Faculty of Accountancy, Universiti Teknologi MARA Melaka
}

\begin{abstract}
Other than debt financing, Initial Public Offerings (IPO) become a common method of capital raising among firms for various purposes. Prospectus is issued on the pre-issuance of the IPO disclosing various mandatory and non-mandatory voluntary information to help the potential investors in their decision making process. Other than financial information on previous and forecasted future performance, the intended use of the IPO's proceeds information is one of the crucial information for the stakeholders especially the investors as they will be the financial contributor for the purposes. In one hand, the issuers may decide to issue highly priced IPO to fulfil their financial needs and other going-public motives. In the other hand, the investors willing to subscribe for the IPO to meet their investment target. The gap between the objectives of these two main stakeholders create uncertainties that may jeopardize the interest of the investors. Thus, the objective of this paper is to investigate the relationship between the intended uses of the IPO's proceed disclosed in the prospectus and their subsequent performance of the stocks. The result of the study can provide input for the investors and other stakeholders for their decision making process to meet their respective objectives.
\end{abstract}

Keywords: Initial Public Offerings, Proceeds, Market Performance

\section{INTRODUCTION}

Around the world, firms may employ various methods to raise funds to meet their short-term and long-term objectives to be sustainable and grow. Two common methods of financing are equity financing and debt financing. While the first does not put the firms into obligation to promise the provider of the funds with returns, but the cost of financing can be too costly to the issuing firms. The later in the other hand comes with some obligations to the firms, but it is less costly.

Even though the cost of issuance of the stocks or equity is expensive, it also comes with advantages. One of the advantages is it can allow outside investor to profit as well which is possible when the stock is under priced (Nelissen, 2016). Equity financing for a firm which issued shares for the first time is called Initial Public Offering (IPO). Most of the IPOs are under priced. Under priced happened when the offer or subscription price determined by the underwriters on behalf of the firms is lower than listing price. Listing price is the price on the first day the share traded in the stock exchange. Various studies conducted to support the under priced of the IPOs such as Rock (1986), Welch (1989), Habib \& Ljungqvist, (1998), Ljungqvist and Wilhelm (2003), and (Leone, Rock, \& Willenborg, 2007). Thus, the under pricing allows the investors to profit from the IPO issuance.

\footnotetext{
*Corresponding author's email: azrina@bdrmelaka.uitm.edu.my
} 
Firms decide to go to public to raise external equity capital for a variety of reasons. One of them is when a firm has insufficient internal fund to make a value-added investment which will accelerate the firms' profit and stock value. Such investments come from various branches such as acquisition of the other firms either for expansion, cost reduction, and elimination of rival purposes. The equity market will provide avenue for the firms to raise fund to implement their plans. An alternative use of proceeds is to repay debt obligations. Since debt financing can sometime be more expensive, some firms may decide to payback its debt by using the proceeds from the IPO (Autore, Bray, \& Peterson, 2009). In Malaysia, the other popular use of the proceeds is to finance their working capital to efficiently manage their cash flows in ensuring operation can be run smoothly.

The intended use of the IPO proceeds can be found in the prospectus which will be issued prior to the issuance of the IPO to give investors information to help them in their investment decision. In Malaysia, all of the firms which seek to be listed in Kuala Lumpur Stock Exchange (KLSE) have to follow the Security Commission Malaysia (SCM) requirement on what information that needs to be discloses in the prospectus. Most of the firms in Malaysia are seeking for funding their investments, payback their debts and to finance their working capital by using the proceeds generated from the IPO issuance. This information on the intended use of the proceeds provide insight about firms' motives and objectives (Autore et al., 2009). Thus, the information might have influence of the stock performance where it can give a picture on how the stocks will be priced in the secondary market (Leone et al., 2007).

The purpose of this study is to investigate the linkages between intended use of the IPO proceeds and the performance of the IPO when it is listed in the stock exchange. We would like to look into how the market react on the information. This can further explain the investors' perception on the decision made by the firms on how the firms intend to utilise the IPO proceeds.

The paper is organised as follows: Section 2 elaborates the literature review on the relevant IPO issues. Section 3 explains the sample selections, proceeds classification and methodology. Lastly, section 4 presents the conclusion, limitation of the study and recommendation for further research.

\section{LITERATURE REVIEW}

\section{The concept of Initial Public Offering (IPO)}

An initial public offering (IPO) occurs when a formerly unlisted company pursues to raise funds from the public capital market by issuing its own equity securities (Balatbat \& Bertinshaw, 2008; Nelissen, 2016). It is the process when a private entity becomes a public company. Accordance to Securities and Exchange Commission (SEC) rules, a company intended to go public must disclose the uses to which it intends to pertain the initial public offering (IPO) proceed (Bray, 2010; Leone et al., 2007) in the prospectus issued. The disclosure is vital for the investors to make sound and informed decision making (Balatbat \& Bertinshaw, 2008).

\section{The intended use of IPO proceeds}

There are different motives why firms raise equity capital. One of the basic doctrines of corporate financial theory is that firms should raise external capital to invest and grow when 
potentially value added investment projects arise with little or none internal funds available for the projects. The equity markets provide a means for firms to sell stock and use the proceeds for investment tenacities, such as acquisitions, capital expenditures, also for research and development. Fundamentally the use of proceeds filed SEC are investment, debt repayment, or general corporate purposes (Autore et., al 2009). The result is coherent with Walker \& Yost (2008) that examined 438 Seasoned Equity Offering (SEO) companies and documented the firm's intended purpose for the proceeds, had identified three specific uses which are investment, debt repayment, and general corporate purposes. Walker and Yost further elaborate the definition of these three categories; 1) Investment; including any proceeds the firm intends to use for increasing the asset base of the firm, the acquisition of other companies and planned spending on research and development. 2) Debt repayment; includes proceeds the firm intends to use to repay any outstanding debt, including revolving credit borrowings. 3) General corporate purposes are reserved for those firms that do not detail up the specific use of funds.

According to (Andriansyah \& Messinis, 2016) the intended use of proceeds is classified into five categories as adopted in (Leone et al., 2007); fixed assets investment; working capital financing; investment in shares of stock; debt repayments and secondary shares. Autore et al., (2009) further stated that some companies might not have a specific purpose for raising equity and might not wish to divulge the intended purpose to the public. However, for the purpose of this study, to focus on three intended proceed namely financing for investment, debt repayment and working capital financing as opposed by simplified version of (Andriansyah \& Messinis, 2016).

\section{The relationship between intended use of IPO proceeds with subsequent share price performance}

Prior empirical studies have been conducted to measure the intended IPO proceeds with the post-issue operating performance (Andriansyah \& Messinis, 2016; Autore et al., 2009; Walker \& Yost, 2008, Busaba, Benveniste, \& Guo (2001) and yet the information has very limited in exploiting the context of post-share price performance of IPO firms especially in Malaysia as stated in (Autore et al., 2009). Thus, future finding of this paper will add contribution towards the literatures as well for the investors and other stakeholders decision making.

A recent comprehensive empirical research has been conducted by (Andriansyah \& Messinis, 2016) that investigates the link between intended use of proceeds and post-issue operating performance of IPO firms among Indonesian equity market over a period of 10 years (20002010). The finding indicates that investment in fixed assets and in stock market shares lead to better performance while other usages lead to insignificant performance. Fixed asset investment and investment in shares in stock, is more notable for average and high performing firms. The above finding is parallel with Autore et al., (2009) that discovered fixed assets investment desirably affect high performing firms. On the other hand, low performing firms might benefit from allocation to working capital financing, debt repayment and secondary shares. The unfavourable effect on low performing firms may relate to the lack of capacity by these firms to manage investment projects effectively.

Walker and Yost (2008) find that regardless of the stated intended use of proceeds, all three classifications (investment, debt repayment, and general corporate purposes) increase investment levels during the three year-period beginning the year prior to the issuance year (years $-1,0$, and +1 ). Furthermore, that issuers stating specific investment plans experience a relatively favorable market reaction at the offer announcement and an improvement in industry-adjusted operating performance. 
Autore, Bray and Peterson (2009) suggest that a comprehensive and clear disclosure on intended use of IPO proceed especially in investment classification will attract investors' interest. Firms which provide solid and distinct disclosure on intended use of proceeds perform better than firms with less disclosure of their use of proceeds (Balatbat \& Bertinshaw, 2008). However, Leone et al. (2007), find lower under pricing when there is greater specificity about the intended use of proceeds.

Meanwhile, Ljungqvist and Wilhelm (2003) reported, when the proceed is to fund operating expenses as opposed to capital expenditure is will lead to greater under pricing which benefited the investors more to meet their respective objectives.

Nevertheless, if the intended use is meant for debt repayment and general corporate purpose the market will not underperformed the benchmark because firm can arrange the timing of IPO issuance. This is consistent with Busaba, et al., (2001) when IPO intended use is for debt repayment, timing is more important rather than use the proceeds for investments.

\section{SAMPLE SELECTION AND PROCEEDS CLASSIFICATION}

\section{Sample selections}

The initial samples of firms which issued IPOs are derived from Bursa Malaysia website for year 2012 to 2015 contributed to the population of this study. Further consideration for the samples is all the samples must have daily closing price subsequent to the listing date which can be retrieved from DataStream database. The samples covered all types of industries. Total firms that can be included in the samples are xxx altogether for the four years both from the Main market and ACE market. The tabulation of the samples is presented in the following table:

Table 1: Sample distribution by year

\begin{tabular}{llll}
\hline Year & Main Market & ACE Market & Total \\
\hline 2012 & 14 & 3 & 17 \\
2013 & 16 & 1 & 17 \\
2014 & 12 & 3 & 15 \\
2015 & 9 & 4 & 13 \\
\hline
\end{tabular}

Table 1 presents the number of IPO issuing firms where in year 2012 and 2013 reported 17 numbers of firms each and in year 2014 and 2015 the numbers are 15 and 13 respectively.

\section{Proceed classifications}

We then manually collect the data on the intended use of the IPO proceeds for each firm from the prospectus issued and newspaper released prior to the IPO issuance. For categorisation purpose, we classify main three specific classifications for the use of the proceeds which represent the largest proportion of the IPO proceeds. They are financing for investment, debt repayment and working capital financing. This is a simplified version of Andriansyah \& Messinis (2016) which includes five classification of intended use; fixed asset investment, working capital financing, investment in shares of stocks, debt repayment and secondary shares.

Issuers in the first classification are those that largest portion of the proceeds will be used for investment purpose (i.e., acquisition of non-current assets such as machineries, premises and 
subsidiaries). Issuers in the second classification meant for firms which the largest portion of the proceeds will be used for debt repayment purpose and issuers in the third classification are those firms that the largest portion of the proceeds will be used for working capital financing. Most of the firms in Malaysia issued IPO for these three main purposes.

\section{CONCLUSION, LIMITATION AND RECOMMENDATION}

\section{Conclusion}

As the IPO issuance become one of the most popular method to raise fund among public firms, this study may provide insight for the issuing firms, policy makers, underwriters and investors on the management of the IPO proceeds. The study may contribute to the shortage of studies on motives of IPO issuance in Malaysia particularly on their influence and ability to direct the reactions of the market. The results of this study provide at least a starting point for the conduct of further research to enhance the knowledge of IPO issuance motives influence on market reactions. Furthermore, this study may provide useful information to investors on how other market participants react on such information. In addition, the results of this study also may help directors and other top managements of a firm to decide how they should manage the proceeds from the IPO issuance to make sure that the benefit of shareholders is not jeopardised as maximizing shareholders wealth is the ultimate goal of a public firm. The results will give the firms a general overview of what investors want.

\section{Limitations}

There are several limitations that can be highlighted since they can be used as a guidance and opportunity for future research. First, limited availability of data and time constraint has made this limitation inevitable. Moreover, the data also may be contaminated by other contemporaneous events. Second, the study only classifies the firms into its classification based on their intended use of the IPO proceeds without any other factors and variables which may influence the investors' reaction. In addition to this, there is no analysis has been done to empirically test the samples selected above.

\section{Recommendations}

The stock performance is closely related to operating performance. Theories proposed that positive earning and operating performance leads to positive investors' reaction which will be the basis for the stock price to be higher and vice versa. Thus, it is worth to investigate further the after-issuance operating performance of the firms in relation to their intended use of initial public offering proceeds. Other than that, it is also worth to further classify the firms into their market capitalization to look into possible impacts on how investors react based on their perception and interpretation of the information released in the prospectus. Hence, further empirical study is required to solve the puzzling issues in IPO performance.

\section{REFERENCES}

Andriansyah, A., \& Messinis, G. (2016). Paci fi c-Basin Finance Journal Intended use of IPO proceeds and fi rm performance: A quantile regression approach is. Pacific-Basin 
Finance Journal, 36, 14-30. http://doi.org/10.1016/j.pacfin.2015.12.001

Autore, D. M., Bray, D. E., \& Peterson, D. R. (2009). Intended use of proceeds and the longrun performance of seasoned equity issuers. Journal of Corporate Finance, 15(3), 358367. http://doi.org/10.1016/j.jcorpfin.2008.12.003

Balatbat, M. C., \& Bertinshaw, S. . (2008). Use of proceeds disclosures in IPO prospectuses : do issuers come clean? The FINSIA Journal of Applied Finance, (2), 17-22.

Bray, D. E. (2010). Two Essays on the Intended Use of Proceeds of Seasoned Equity Offerings.

Busaba,W.Y., Benveniste, L.M., Guo, R., 2001. The option to withdraw IPOs during the premarket: empirical analysis. Journal of Financial Economics 60, 73-102.

Habib, M. A., \& Ljungqvist, A. P. (1998). Underpricing and IPO proceeds : a note, 61, 381383.

Leone, A. J., Rock, S., \& Willenborg, M. (2007). Disclosure of Intended Use of Proceeds and Underpricing in Initial Public Offerings, 45(1). http://doi.org/10.1111/j.1475679X.2006.00229.x

Ljungqvist, A., Wilhelm,W., 2003. IPO pricing in the dot-com bubble. Journal of Finance 58, $723-752$

M.D. Walker, K. Yost . Seasoned equity offerings: What firms say, do, and how the market reacts Journal of Corporate Finance 14 (2008) 376-386.

Nelissen, B. B. (2016). First-day overperformance of IPOs, (May).

Welch, I., (1989). Seasoned offerings, imitation costs, and the under pricing of initial public offerings. Journal of Finance 44, 421-450. 